\title{
Resolving back pain: a case of untreated discitis
}

\author{
Othman Kirresh, Peter Williams
}

Department of Rheumatology, Medway Maritime Hospital, Kent, UK

\section{Correspondence to}

Dr Othman Kirresh,

othmankirresh@doctors.org.uk

Accepted 20 April 2014

\section{DESCRIPTION}

A 69-year-old man was investigated by gastroenterology for iron deficiency anaemia associated with a 2-month history of mid-lower back and shoulder stiffness on returning from holiday in Sicily. He was found to have an erythrocyte sedimentation rate (ESR) of $41 \mathrm{~mm} / \mathrm{hr}$ and $\mathrm{C}$ reactive protein (CRP) of $166 \mathrm{mg} / \mathrm{L}$ and was started on prednisolone for presumed polymyalgia rheumatica (PMR) to which he responded dramatically. Subsequent CT scan showed a potential inflammatory focus in the vertebrae, with no obvious occult malignancy.

On referral to rheumatology, 1 month later MRI of the spine (figure 1) demonstrated an aggressive multilevel discitis at T7/T8, T9/10 and L3/L4. A

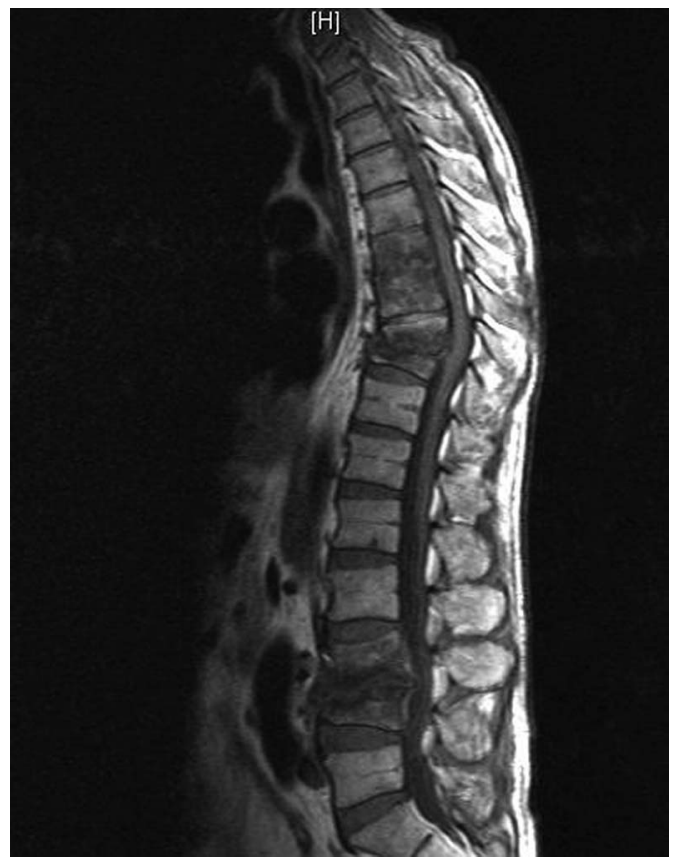

Figure 1 MRI T1 sagittal view of the whole spine. single-photon emission (SPECT) bone scan (figure 2) confirmed abnormal uptake in the above areas suggestive of discitis. Clinically he was well, asymptomatic with no constitutional symptoms.

On review with the spinal surgeons and microbiologists it was not felt justified to treat the patient based on radiology alone. Further biopsy, blood cultures and comprehensive serology including brucella were negative, CRP and ESR remained normal since the introduction of steroids for PMR.

A further white cell scan (figure 3) showed no significant accumulation of tracer identified at the thoracic or lumbar spine at 24 and $72 \mathrm{~h}$ after injection with no convincing evidence of active discitis.

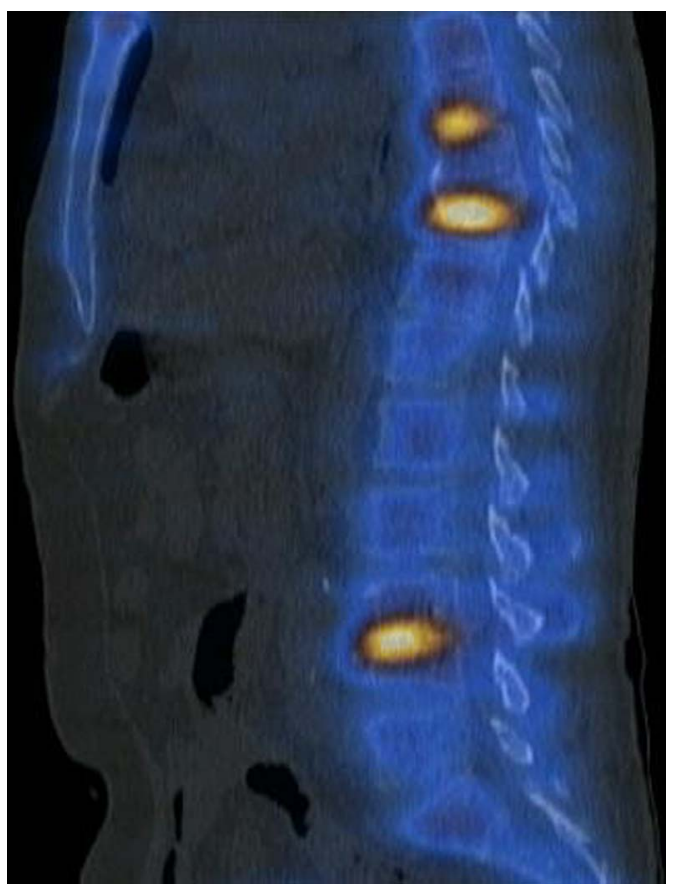

Figure 2 Nuclear medicine whole body bone scan with single-photon emission CT. Abnormal uptake in the thoracic (T7-T10) and lumbar area (L3-L4) highly suggestive of discitis. 


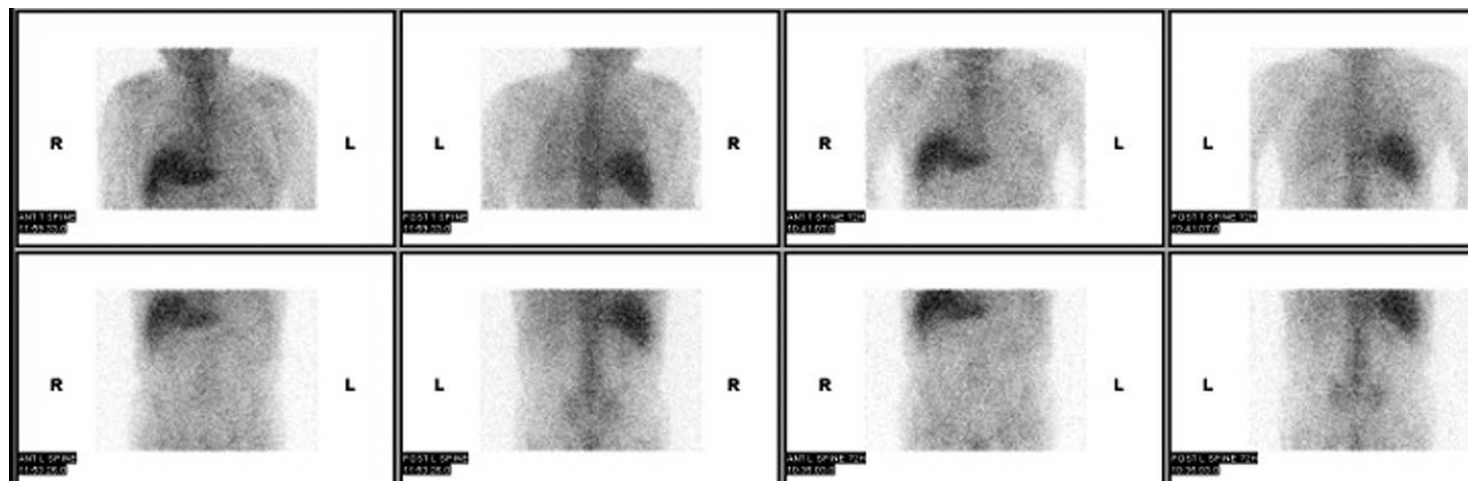

Figure 3 Nuclear Medicine Gallium scan (whole body). No significant accumulation of tracer noted in the thoracic or lumbar area 24 and $72 \mathrm{~h}$ post injection.

\section{Learning points}

- Diagnosing discitis can be challenging in some patients and relatively straightforward in others. It is usually first suspected on a basis of clinical features and abnormal radiographic and/or radionuclide scanning findings. ${ }^{1}$ It is then confirmed either by blood cultures (positive in $50-70 \%$ ) or by more invasive diagnostic tests usually involving aspiration of the infected intervertebral disc space. Every effort should be made to identify the pathogen before starting antimicrobial treatment. ${ }^{2}$

- If blood cultures and needle aspirate are negative and the clinical suspicion of discitis remains high on the basis of clinical and radiographic findings, a sensible decision regarding treatment needs to be made. In this scenario although the imaging is alarming the patient was clinically asymptomatic, and systemically well, and ESR and CRP remained normal. Justifying the use of long-term antibiotic therapy without an obvious source provides difficulty.

- It is therefore important to have a multidisciplinary (microbiologists, radiologists, rheumatologists, spinal orthopaedics) approach particularly when dealing with the management of a complex pathology to agree on the best outcome for the patient. The main question raised in this case, was whether to treat the discitis with antibiotics. It must be noted that antibiotics can also have their associated complications particularly if used for a prolonged duration.
He remains well on a gradually tapering dose of prednisolone for presumed PMR, six months after discitis was first identified on MRI without antibiotic therapy. He is reviewed regularly in rheumatology and awaits an interval MRI.

Competing interests None.

Patient consent Obtained.

Provenance and peer review Not commissioned; externally peer reviewed.

\section{REFERENCES}

1 Palestro CJ, Torres MA. Radionuclide imaging in orthopedic infections. Semin NuCl Med 1997;27:334.

2 Kulowski J. Pyogenic, vertebral osteomyelitis of the spine: an analysis and discussion of 102 cases. J Bone Joint Surg 1936;1:343. 
Copyright 2014 BMJ Publishing Group. All rights reserved. For permission to reuse any of this content visit http://group.bmj.com/group/rights-licensing/permissions.

BMJ Case Report Fellows may re-use this article for personal use and teaching without any further permission.

Become a Fellow of BMJ Case Reports today and you can:

- Submit as many cases as you like

- Enjoy fast sympathetic peer review and rapid publication of accepted articles

- Access all the published articles

- Re-use any of the published material for personal use and teaching without further permission

For information on Institutional Fellowships contact consortiasales@bmjgroup.com

Visit casereports.bmj.com for more articles like this and to become a Fellow 